\title{
The Behavioral Intention's Role: Facilitating Condition and Use of E-Government Services among SMEs in Saudi Arabia
}

\author{
Aljerais Turki Mansour', Huda Ibrahim², Syahida Hassan ${ }^{3}$ \\ ${ }^{1,2,3}$ School of Computing, College of Arts and Sciences, Universiti Utara Malaysia \\ aljeraisturki@gmail.com¹, huda753@uum.edu.my ${ }^{2}$, syahida@uum.edu.my ${ }^{3}$
}

Article History: Received: 10 November 2020; Revised: 12 January 2021; Accepted: 27 January 2021; Published online: 05 April 2021

\begin{abstract}
Saudi government plan to digitize all governmental services, but that may encounter several issues such as the familiarity of citizens with electronic version of services. This study was conducted to identify the factors that influence the use behavior of e-government service among employees of SMEs in Saudi Arabia. This article addresses the effect of behavioral intention as a mediation factor between facilitating condition and the use of e-government services among SMEs in Saudi Arabia. The data were collected from SMEs operating in Riyadh region and SEM-AMOS software was used for data analysis. It was found that the behavioral intention mediates the relationship between Facilitating condition and the use behavior The results provide the importance of facilitating condition which linked with the output of the use behavior.
\end{abstract}

Keywords: Behavior intention, e-government services, SMEs, Saudi Arabia.

\section{Introduction}

E-government services can be of great value and importance in the 21 st century for efficient growth and responsive cost saving. E-government, particularly by multinationals and SMEs, has become a common practice in the developed economies. Saudi Arabia is lagging behind in terms of government's online services compared to other Gulf Cooperation Council (GCC) states such as UAE and Bahrain (Alshehri and Drew, 2010). Practically, through transforming from conventional paper-based processes to e-services using technology and the Internet, the government can provide more responsive service with greater customer facilitation and satisfaction, which resulted in very crucial change in the entire Saudi Arabia public sector; its values, culture and operations (Alzahrani et al., 2017). Saudi government uses Absher, an online portal implemented by KSA for users to access online services anytime and anywhere. Absher provides facilities to the citizen and visitors for immigration matters. It has users that number up to four millions and thus increasing usability of Absher portal is necessary (Al-Khateeb et al., 2015). Based on the study by El-sofany et al. (2012), people require assurance and confidence in the e-services that their information will not be mishandled upon using e-services. In KSA, people are reluctant to share personal information over the internet due to lack of reliance on the privacy of the information. More particular, Akhbaar (2014) indicates that most of the workforce at SMEs prefer physical interaction in immigration matters to avoid any potential risk concerning to information security.

It has been found that awareness of the system related facility is one of the barriers that affect the adoption of e-government services (AlNuaimi et al., 2011, Luo et al., 2011). According to Alghamdi and Beloff (2016), facilitating condition is a major problem which causes lack of use behavior of e-services in Saudi Arabia. On other hand; Alzahrani et al. (2018) stated that individuals use Absher online services to get their task done, they don't use Absher services to feel pleasure.

According to Almoawi and Mahmood (2011), there is insufficient research the usage of e-services by SMEs. The review of the literatures so far shows no single article reporting on a study of the usage of the government's immigration e-services among the SMEs' employees in Saudi Arabia. In addition, the problems and obstacles faced on general grounds by citizens while using e-services might also turn out to be the same in e-services use of Absher by SMEs workers in Saudi Arabia. As stated by Sharma (2015), previous e-government services studies have overlooked to address this crucial issue that concern the problem of using e-services among employees of SMEs in Saudi Arabia. The majority of these studies focused more on public sectors where they examined the factors that affect the use behavior of employees in public sector organizations toward e-services (Al-Hujran et al., 2015) with few interests shown in the private sector. More information is not revealed regarding the use of e-government services among employees of SMEs.

With this gap, therefore, our study has investigated the impact of facilitating conditions on e-government use among employees of SMEs in Saudi Arabia. The scope is on the factors that influence employees of SMEs on the use behavior of e-services (Absher). It seeks to provide significant evidence on the effect of e-services toward supporting SMEs through enabling employees to use e-services and thereby could significantly affect the 
performance of SMEs. The results give a deep understanding on the direct effect of government agencies on the businesses through the e-services that provided for employees and local citizens in general and thereby supporting SMEs for growth and survival as well.

\section{Literature Review}

According to Silva (2017), Saudi Arabia has ranked $44^{\text {th }}$ worldwide for its E-Government Development Index in 2016 compared to 58 in 2010. Based on Saudi National e-government Strategy and Second Action Plan (2012-2016), there were initiatives such as increase number and maturity of e-services for all government agencies, deploy e-services through channels available and accepted by the public (Yesser, 2012). Practically, through transforming from conventional paper-based process to e-services using technology and the Internet, the government can provide more responsive services with greater customer facilitation and satisfaction, which resulted in very crucial change in the entire Saudi Arabia public sector; its values, culture and operations (Alzahrani et al., 2017).

One of the main e-government initiatives in Saudi Arabia that provides facilities and enhances citizens faster use e-services is "Absher" electronic platform. Absher is one of the projects that has implemented the egovernment strategy in Saudi Arabia. It was launched through electronic gate of Ministry of interior to facilitate the procedures of the issuance and renewal of travel permits, the residence and the visas, and access to personal and family data through the internet (Al-Khateeb et al., 2015). Absher helps employees in the different companies across the Kingdom to settle their residence related tasks in the accurate time and place and hence would be a useful way to increase employee's satisfaction and their productivity (Alotaibi, 2015). Actually, Absher is concerning all information and documents about international residents as well as local citizens. According to Saudi General Authority for Statistics, the number of workers in Saudi Arabia reached 13.76 million at the end of the third quarter of 2017, that is 77.7 percent or 10.69 million of whom were foreigners compared to 22.3 percent or 3.06 million Saudis. Using Absher, workers can handle all their needs regarding visa, work permit, business information, laws, rules, and regulations, renewal of residence, health insurance, and personal data. The statistics also revealed that the number of foreigners working in SMEs has reached 3.71 million people out of 4.72 million employees who work in 949,86,000 SMEs (Middleeastmonitor, 2018).

\section{SMEs in Saudi Arabia}

Importantly, SMEs play a very active role in every economy and towards the GDP. Reports have also outlined and signified towards the role and contribution of SMEs towards the national GDP (Jinjarak and Wignaraja, 2016, Awheda et al., 2016). SMEs in Saudi Arabia have a significant effect as the most critical players for local economy, which influences domestic economy in several aspects such as employment, easy of diffusion, providing wide range of products, flexibility to deal with any economic crisis. This significance potentially leads to revisiting the idea as to how the performance of SMEs could be further enhanced by local, regional and global levels to gain the maximum benefits (Bahaddad et al., 2012). As SMEs provide greater opportunities through employment to individuals and contributing towards annual GDP (Rakićević et al., 2016, Cerrato et al., 2016), if they are facilitated and supported further through bringing services that are convenient, user-friendly and cost effective, this will certainly enhance their performance and productivity. Previously, due to the unavailability of the responsive e-services in different public agencies that offered for local and international employees and citizens as well, the individuals have to take days off, stand in the queue for long hours and go to several offices for completing the paperwork which can significantly affect their performance and the overall productivity of the SMEs. Accordingly, Saudi Arabia requires looking at how it could further strengthen its e-services for immigration purposes to facilitate SMEs with regards to their workforce and work related matters. This will certainly enhance their performance and productivity and also the welfare of SME staff to use e-service for the perusal of their immigration related tasks that would result in improving their business.

\section{Model Development}

The focus of this article is on facilitating condition and its relationship to behavioral intention and use of eservice. Facilitating conditions is defined as the perceptions of individuals that technical and organizational infrastructure required to use and support an intended system are available and thus intention to adopt new technologies should not be an issue (Venkatesh et al., 2003). Previous studies have included facilitating condition as influential factor in the use of e-government services. Facilitating condition was found critical construct in describing e-government use (Alotaibi et al., 2014, Alshehri et al., 2013). 
Facilitating conditions has a significant effect on behavioural intention towards using ICT (Luo et al., 2011). The influence of facilitating conditions on the behavioural intention of individuals to use a new system has been examined in the literature in different contexts such as mobile learning (Thomas et al., 2013), electronic tickets (Wu et al., 2012), social media (Harsono and Suryana, 2014), and online banking (Foon and Fah, 2011, Khan et al., 2017). In the context of e-government, previous studies show that facilitating condition have positive impact on the behavioural intention to use e-government services (Gupta et al., 2008; Venkatesh et al., 2003). Alraja (2016) investigated facilitating conditions impact on employees' intention to adopt e-government in Sultanate of Oman. Further, Voutinioti (2013) concluded that facilitating conditions has direct effect and significant on citizens behavioural intention to us e-government services in Greece. In this study, there is a potential to see FC could have influenced the behavioural intention to use of e-services among SMEs. Thus a hypothesis can be proposed in the context of SMEs' employees in Saudi Arabia to adopt e-government services.

H1: Facilitating Condition influences behavioural intention of SMEs employees to use E-Government Services in Saudi Arabia.

Facilitating conditions influence technology use directly based on the idea that facilitating conditions can serve as the proxy for behavioural control and influence behaviour directly (Ajzen, 1991). This is because many aspects of facilitating conditions, such as training and support, may be freely available within the company and fairly invariant across user likely to have a higher intention to use a technology. Alghamdi and Beloff (2016) found that the facilitating conditions has a positive effect on online services use.facilitating conditions can have direct effect on use behaviour in the context of e-government services adoption (Alshehri et al., 2013); (Krishnaraju et al., 2016). Accordingly, this research examines facilitating condition influence use behaviours of employees in Saudis' SMEs.

Facilitating condition is one of the major reasons explaining the use behaviour of individuals towards technologies (Ghalandari and Norouzi, 2012, Sargent et al., 2012). Almatari et al. (2013) showed that facilitating conditions has positive impact on the use behaviour of students towards m-learning. Facilitating conditions also was examined in the context of e-health to test its effects on the actual use of Electronic Patient Record by nurses. In the context of e-government, Al-Azri et al. (2010) have argued that adopting e-government is not an easy task due to the fact that there is a thorough involvement of technical, human and managerial factors which collectively facilitate the process. Previous studies show that facilitating condition have positive impact on the egovernment use behaviour of the citizen (Gupta et al., 2008, Venkatesh et al., 2003). AlAwadhi and Morris (2009) identified facilitating condition as one of the main factors that could influence citizens to use egovernment services.

Hence the study proposed:

$\mathrm{H} 2$ : Facilitating condition positively influences the SMEs employees' behaviour use of e-government services in Saudi Arabia.

Al-Hujran et al. (2015) stated that citizen intention is an important factor to outline and influence the use of e-government services. Intentions are converted to use, and the citizen's intention should not be ignored when they are looking towards use of e-government service Al-Hujran et al. (2015). Alateyah et al. (2013) stated that intention to use e-government can considerably influence the e-government service usage. Al Imarah et al. (2013) found a relation between behavioural intention and academic staffs' use of e-government services. The intention of utilizing as a behaviour comprises of the prediction of expressions of general citizens towards the egovernment systems and their use. The prediction of their intentions is important to outline and examine the influence on behaviour of use (Ajzen, 1991, Venkatesh et al., 2003). Hence, the following hypothesis is proposed:

H3: Behavioural intention significantly influences the use of e-government service by SMEs employees in Saudi Arabia.

The above discussion can be represented in the model (figure 1).

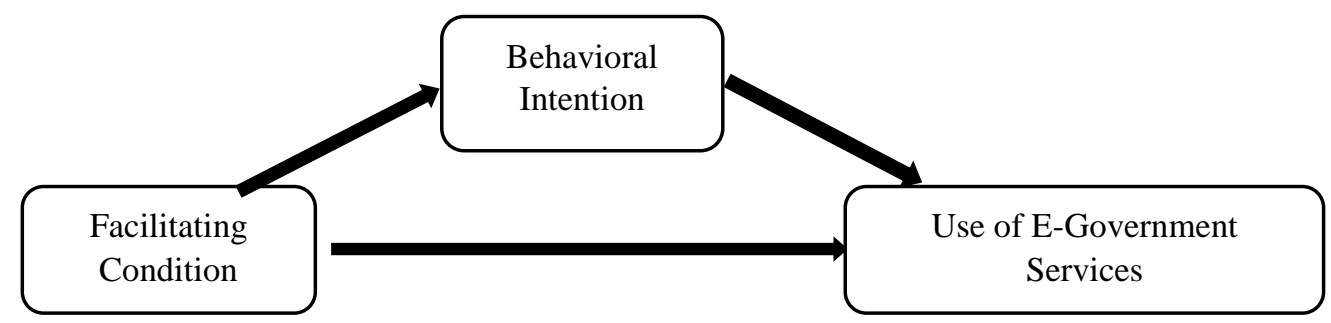

Figure 1. Research Framework 


\section{Methodology}

Data collection was done from September 2016 to February 2017 in Riyadh, Saudi Arabia, the capital city of Saudi Arabia. The e-government efforts are largely focused on this biggest city (Al-Sobhi \& Weerakkody, 2010). The researcher applied cross-sectional data and survey of strategy, among the most used technique when involve a large number of participants. The target population for this study is employees working in SMEs in the Kingdom of Saudi. There are more than 40,000 employees work in all SMEs registered under the city of Riyadh. Thus the population is 447987 people working in 91894 SMEs. The sample size is 1169 people.

A five-point scale measurement was applied to get responses. According to Dawes (2008) the five-point Likert scale is able to improve reliability of the measures comparative to seven or three point scale. Four items were used to measure facilitating condition. Those items have been adapted from a study of Venkatesh et al. (2003). The four items of use behavior adapted from a study of Aladwani (2006) related to e-government services. Finally; the questionnaires were reviewed by experts. From the 1169 questionnaires distributed, 477 sets were returned to which 443 responses were useful for analysis. The response rate of this study is $41 \%$, which is considered good (Baruch and Holtom, 2008) in comparison to other studies found in the relevant literature.

\section{Analysis}

The respondents' information is summarized using basic descriptive statistics such as frequencies and percentages in order to provide overview of the data collected. Table 1 shows the frequency and percentage for demographic profile of respondents in the study sample. It shows that $357(80.6 \%)$ respondent are male while the rest $86(19.4 \%)$ are female participants. Regarding age groups of the sample, $17.8 \%$ of them are between 18 and 25 years old, $25.5 \%$ of total respondents between 26 and 34, 34.3\% of total respondents are in the age group of 35 to 42 years, $15.6 \%$ between 43 and 50, and $6.8 \%$ of total respondents are above 50 years. In terms of education background, $5.6 \%$ of respondents have high school certificate, respondents who have bachelor degree represent the majority of participation which is about $60.7 \%$. Meanwhile, $25.9 \%$ of respondents finished their postgraduate studies. From the survey, majority of respondents are citizen which represent $75.8 \%$, whilst $24.2 \%$ of respondents are resident. Regarding the duration of internet usage, $2.7 \%$ of respondents have experince less than 1 years, $4.5 \%$ of total respondents between 1 and 3 years, 12\% between 4 and 5 years, 28.7\% between 6 and 10 years, and $52.1 \%$ of total respondents are above 10 years.

Table 1. Summary of Demographic Profile of Respondents

\begin{tabular}{|c|c|c|c|c|}
\hline No & Demographic Item & Categories & Frequency & Percentage \\
\hline \multirow[t]{2}{*}{1} & Gender & 1. Male & 357 & 80.6 \\
\hline & & 2. Female & 86 & 19.4 \\
\hline \multirow[t]{5}{*}{2} & Age & 1. $18-25$ years & 79 & 17.8 \\
\hline & & 2. $26-34$ years & 113 & 25.5 \\
\hline & & $3.35-42$ years & 152 & 34.3 \\
\hline & & 4. 43 - 50 years & 69 & 15.6 \\
\hline & & 5.Above 50 years. & 30 & 6.8 \\
\hline \multirow[t]{5}{*}{3} & Education & 1. High School & 25 & 5.6 \\
\hline & Background & 2. Bachelor Degree & 269 & 60.7 \\
\hline & & 3. Master & 63 & 14.2 \\
\hline & & 4. $\mathrm{PhD}$ & 52 & 11.7 \\
\hline & & 5. Other & 34 & 7.7 \\
\hline \multirow[t]{2}{*}{4} & Nationality & 1. Citizen & 336 & 75.8 \\
\hline & & 2. Resident & 107 & 24.2 \\
\hline \multirow[t]{2}{*}{5} & Own computer or & 1. Yes & 420 & 94.8 \\
\hline & smartphone & 2. No & 23 & 5.2 \\
\hline \multirow[t]{4}{*}{6} & The place to use the e- & 1. Office & 23 & 5.2 \\
\hline & services & 2. House & 161 & 36.3 \\
\hline & & 3. Cafe & 53 & 12.0 \\
\hline & & 4. All of them & 206 & 46.5 \\
\hline \multirow[t]{5}{*}{7} & Frequently use online & 1. SMS & 209 & 47.2 \\
\hline & services options of & 2. MMS & 7 & 1.6 \\
\hline & Absher & 3. Ringtoneand logo download & 4 & 0.9 \\
\hline & & 4. Java games & 10 & 2.3 \\
\hline & & 5. Browse websites & 142 & 32.1 \\
\hline
\end{tabular}


The Behavioral Intention's Role: Facilitating Condition and Use of E-Government Services among SMEs in Saudi Arabia

\begin{tabular}{lllcc}
\hline \hline No & Demographic Item & Categories & Frequency & Percentage \\
\hline & & 6. Mobile e-email note & 71 & 16.0 \\
\hline 8 & Duration of & 6. Less than 1 years & 12 & 2.7 \\
& Internet Usage & 2. 1 - 3 years & 20 & 4.5 \\
& & 3.4 - 5 years & 53 & 12.0 \\
& 4. 6 - 10 years & 127 & 28.7 \\
& 5. above 10 years & 231 & 52.1 \\
\hline \hline
\end{tabular}

Source: Survey

Table 2 presents the frequency, percentage, mean and standard deviation of each item which measures behavioral intention (BI) among respondents. A respondent was asked to indicate his or her opinion which is measured on five-point scale as follow: 1 (never), 2 (once a month), 3 (once a week), and 4 (every day or two), and 5 (several times a day). Generally, the results indicated the overall respondents' mean score for behavioral intention in the current study is 3.18 with a standard deviation of 1.187 . This indicates that the respondents intend to continue using e-service provided by Absher in the future.

Table 2. Mean and standard deviation of behavioral intention (BI)

\begin{tabular}{|c|c|c|c|c|c|c|c|c|c|}
\hline No. & Items & $\begin{array}{l}1 \\
\mathrm{n} \\
\%\end{array}$ & $\begin{array}{l}2 \\
\mathrm{n} \\
\%\end{array}$ & $\begin{array}{l}3 \\
\mathrm{n} \\
\%\end{array}$ & $\begin{array}{l}4 \\
\mathrm{n} \\
\%\end{array}$ & $\begin{array}{l}5 \\
\mathrm{n} \\
\%\end{array}$ & M & SD & Rank \\
\hline BI1 & $\begin{array}{l}\text { I intend to continue using } \\
\text { e-service provided by Absher in } \\
\text { the future. }\end{array}$ & $\begin{array}{l}36 \\
8.1\end{array}$ & $\begin{array}{c}107 \\
24.2\end{array}$ & $\begin{array}{c}110 \\
24.8\end{array}$ & $\begin{array}{c}119 \\
26.9\end{array}$ & $\begin{array}{c}71 \\
16.0\end{array}$ & 3.19 & 1.202 & 2 \\
\hline $\mathrm{BI} 2$ & $\begin{array}{l}\text { I will always try to use e-service } \\
\text { provided by Absher in my daily } \\
\text { life. }\end{array}$ & $\begin{array}{l}43 \\
9.7\end{array}$ & $\begin{array}{c}98 \\
22.1\end{array}$ & $\begin{array}{c}109 \\
24.6\end{array}$ & $\begin{array}{c}129 \\
29.1\end{array}$ & $\begin{array}{c}64 \\
14.4\end{array}$ & 3.16 & 1.153 & 3 \\
\hline $\mathrm{BI} 3$ & $\begin{array}{l}\text { I plan to continue to use eservice } \\
\text { provided by Absher frequent. }\end{array}$ & $\begin{array}{l}33 \\
7.4\end{array}$ & $\begin{array}{c}101 \\
22.8\end{array}$ & $\begin{array}{r}114 \\
25.7\end{array}$ & $\begin{array}{l}136 \\
30.7\end{array}$ & $\begin{array}{c}59 \\
13.3\end{array}$ & 3.20 & 1.153 & 1 \\
\hline & Total & & & & & & 3.18 & 1.187 & \\
\hline
\end{tabular}

Source: Survey. Note: $\mathrm{n}=$ frequency; $\%=$ percentage; $1=$ never; $2=$ once a month; $3=$ once a week; $4=$ every day or two; $5=$ several times a day; $\mathrm{M}=$ Mean; $\mathrm{SD}=$ Standard Deviation

Table 3 presents the frequency, percentage, mean and standard deviation of each item which measures facilitating conditions (FC) among respondents. A respondent was asked to indicate their opinion which is measured on five-point scale ranging from 1 (strongly Disagree) to 5 (strongly Agree). The third item records the highest mean score of 3.37 out of 5.0 point with a standard deviation of 1.208 indicating that the respondents agree that E-services of Absher is compatible with other technologies they use. Generally, the results indicate the overall respondents' mean score for facilitating conditions in the current study is 3.31 with a standard deviation of 1.203. This has indicated that the respondents agree that they have the resources and knowledge necessary to facilitate them to use Absher Services, and they can get help from others when they have difficulties using eservices of Absher.

Table 3. Mean and standard deviation of facilitating conditions (FC)

\begin{tabular}{|c|c|c|c|c|c|c|c|c|c|}
\hline \multirow[t]{3}{*}{ No. } & Items & 1 & 2 & 3 & 4 & $\overline{5}$ & \multirow{3}{*}{ M } & \multirow{3}{*}{ SD } & \multirow{3}{*}{ Rank } \\
\hline & & $\mathrm{n}$ & $\mathrm{n}$ & $\mathrm{n}$ & $\mathrm{n}$ & $\mathrm{n}$ & & & \\
\hline & & $\%$ & $\%$ & $\%$ & $\%$ & $\%$ & & & \\
\hline \multirow[t]{2}{*}{ FC1 } & I have the resources necessary & 45 & 77 & 108 & 118 & 95 & \multirow[t]{2}{*}{3.32} & \multirow[t]{2}{*}{1.268} & \multirow[t]{2}{*}{2} \\
\hline & to use Absher Services. & 10.2 & 17.4 & 24.4 & 26.6 & 21.4 & & & \\
\hline \multirow[t]{2}{*}{$\mathrm{FC} 2$} & I have the knowledge necessary & 35 & 84 & 105 & 142 & 77 & \multirow[t]{2}{*}{3.32} & \multirow[t]{2}{*}{1.192} & \multirow[t]{2}{*}{2} \\
\hline & to use Absher Services. & 7.9 & 19.0 & 23.7 & 32.1 & 17.41 & & & \\
\hline \multirow{2}{*}{ FC3 } & E-services of Absher is & 35 & 77 & 110 & 132 & 89 & \multirow[t]{2}{*}{3.37} & \multirow[t]{2}{*}{1.208} & \multirow[t]{2}{*}{1} \\
\hline & $\begin{array}{l}\text { compatible with other } \\
\text { technologies I use. }\end{array}$ & 7.9 & 17.4 & 24.8 & 29.8 & 20.1 & & & \\
\hline \multirow[t]{3}{*}{ FC4 } & I can get help from others when & 31 & 99 & 113 & 141 & 59 & \multirow[t]{2}{*}{3.22} & \multirow[t]{2}{*}{1.144} & \multirow[t]{2}{*}{4} \\
\hline & $\begin{array}{l}\text { I have difficulties using } \\
\text { eservices of Absher. }\end{array}$ & 7.0 & 22.3 & 25.5 & 31.8 & 13.3 & & & \\
\hline & Total & & & & & & 3.31 & 1.203 & \\
\hline
\end{tabular}

Source: Survey 
Note: $\mathrm{n}=$ frequency; $\%=$ percentage; $1=$ strongly Disagree $2=$ Disagree; $3=$ Neutral; $4=$ Agree; $5=$ strongly Agree; $\mathrm{M}=$ Mean; $\mathrm{SD}=$ Standard Deviation

Table 4 presents the frequency, percentage, mean and standard deviation of each item which measures use behavior (USE) among respondents. A respondent is asked to indicate their opinion which is measured on fivepoint scale as follow: 1 (never), 2 (once a month), 3 (once a week), 4 (every day or two), and 5 (several times a day). Generally, the results indicate the overall respondents' mean score for use behavior in the current study is 2.97 with a standard deviation of 1.214 , indicate that the respondents frequently use egovernment services provided by Absher at least once a week and on a regular basis.

Table 4. Mean and standard deviation of use behavior (USE)

\begin{tabular}{|c|c|c|c|c|c|c|c|c|c|}
\hline \multirow[t]{3}{*}{ No. } & \multirow[t]{3}{*}{ Items } & 1 & 2 & 3 & 4 & $\overline{5}$ & \multirow{3}{*}{ M } & \multirow{3}{*}{ SD } & \multirow{3}{*}{ Rank } \\
\hline & & $\mathrm{n}$ & $\mathrm{n}$ & $\mathrm{n}$ & $\mathrm{n}$ & $\mathrm{n}$ & & & \\
\hline & & $\%$ & $\%$ & $\%$ & $\%$ & $\%$ & & & \\
\hline \multirow[t]{2}{*}{ USE1 } & I really want to use e- & 46 & 145 & 92 & 87 & 73 & 2.99 & 1.131 & 2 \\
\hline & $\begin{array}{l}\text { government services provided } \\
\text { by Absher to perform my task } \\
\text { related immigration. }\end{array}$ & 10.4 & 32.7 & 20.8 & 19.6 & 16.5 & & & \\
\hline \multirow[t]{2}{*}{ USE2 } & I frequently use e-government & 52 & 116 & 125 & 98 & 52 & 2.96 & 1.073 & 3 \\
\hline & services provided by Absher. & 11.7 & 26.2 & 28.2 & 22.1 & 11.7 & & & \\
\hline \multirow[t]{2}{*}{ USE3 } & I use e-government services & 56 & 119 & 122 & 101 & 45 & 2.91 & 1.107 & 4 \\
\hline & $\begin{array}{l}\text { provided by Absher on a regular } \\
\text { basis. }\end{array}$ & 12.6 & 26.9 & 27.5 & 22.8 & 10.2 & & & \\
\hline \multirow[t]{3}{*}{ USE4 } & Most of my governmental & 50 & 116 & 117 & 102 & 58 & 3.00 & 1.114 & 1 \\
\hline & $\begin{array}{l}\text { requests and immigration tasks } \\
\text { are done through e-government } \\
\text { services provided by Absher. }\end{array}$ & 11.3 & 26.2 & 26.4 & 23.0 & 13.1 & & & \\
\hline & Total & & & & & & 2.97 & 1.214 & \\
\hline
\end{tabular}

Source: Survey

Note: $\mathrm{n}=$ frequency; $\%=$ percentage; $1=$ never; $2=$ once a month; $3=$ once a week; $4=$ every day or two; $5=$ several times a day; $\mathrm{M}=\mathrm{Mean} ; \mathrm{SD}=$ Standard Deviation

The hypotheses of this study were tested using structural equation modeling via AMOS. The structural model assessment as shown in Table 5 provides the indication of the hypotheses tests. However, facilitating condition are rejected and the study confirmed that no effect of this variable on the use of e-government services among SMEs in Saudi Arabia as presented in the table 5.

Table 5. Structural Path Analysis Result

\begin{tabular}{|l|l|l|l|l|l|l|}
\hline Hypothesis & DV & IV & $\begin{array}{l}\text { Estimate } \beta \\
\text { (Path coefficient) }\end{array}$ & S.E & C.R & $\begin{array}{l}\text { Hypothesis } \\
\text { Result }\end{array}$ \\
\hline H1 & BI & FC & 0.30 & 0.054 & $\begin{array}{l}5.942 * * \\
*\end{array}$ & Supported \\
\hline H2 & USE & FC & 0.07 & 0.075 & 0.977 & Not Supported \\
\hline H3 & USE & BI & 0.58 & 0.066 & $\begin{array}{l}8.867 * * \\
*\end{array}$ & Supported \\
\hline
\end{tabular}

Note: FC: facilitating condition, USE: use behavior

$* * * \mathrm{p}<.001 ; * * \mathrm{p}<.01 ; * \mathrm{p}<.05$

S.E $=$ Standard Error

C.R $=$ Critical Ratio

Table 6 shows the results of composite reliability values greater than 0.7 , and the Cronbach's alpha also greater than 0.7, which indicates that the construct reliability is fulfilled, and there is both consistency and stability in the model(Hair et al., 2013, Hair and Anderson, 1998, Hair et al., 2017).

Table 6. Cronbach's Alpha and composite reliability results

\begin{tabular}{|l|l|l|}
\hline Construct & $\alpha$ (above 0.7$)$ & CR $(>0.7)$ \\
\hline FC & 0.922 & 0.924 \\
\hline BI & 0.938 & 0.938 \\
\hline USE & 0.932 & 0.933 \\
\hline
\end{tabular}


Note: $\alpha=$ Cronbach's alpha; $\mathrm{CR}=$ Composite Reliability

Key: FC: facilitating condition, BI: behavioral intention, USE: use behavior

Table 7 shows the result of the Convergent validity via Average variance extracted (AVE), which indicates that all AVE values are higher than 0.50. Convergent validity of the full model construct is fulfilled(Hair et al., 2013, Hair et al., 2017).

Table 7. Average variance extracted (AVE) results

\begin{tabular}{|l|l|}
\hline Construct & AVE $(>0.7)$ \\
\hline FC & 0.754 \\
\hline BI & 0.835 \\
\hline USE & 0.778 \\
\hline
\end{tabular}

Note: AVE $=$ Average Variance Extracted

Key: FC: facilitating condition, BI: behavioral intention, USE: use behavior

As it is seen in table 5 that FC has insignificant direct impact on USE. Then, it is expected there is indirect impact via BI. Table 8 shows the result of the bootstrapping analysis, indicating that the indirect effect $\beta=0.174$ was significant with a t-value of 4.047. Further, Preacher and Hayes (2008) indicate that the 0.174, 95\% Boot CI: $[\mathrm{LL}=0.447, \mathrm{UL}=0.617]$ does not straddle a 0 in between, this indicating there is mediation. Thus, this study can conclude that the mediation effect of the behavioral intention is statistically significant between facilitating condition and use behavior, indicating that $\mathrm{H} 1$ was also supported.

Table 8. Mediation effect of intention between facilitating condition and use behavior by bootstrapping

\begin{tabular}{lllll}
\hline \hline Relationship & Std Beta & Std Error & t-value & Hypothesis Result \\
\hline $\mathrm{FC} \rightarrow \mathrm{BI} \rightarrow \mathrm{USE}$ & 0.174 & 0.043 & $4.047^{* * *}$ & Supported \\
\hline \hline
\end{tabular}

(Preacher and Hayes2004, 2008)

Note: : FC: facilitating condition, BI: behavioral intention, USE: use behavior

$* * * \mathrm{p}<.001 ; * * \mathrm{p}<.01 ; * \mathrm{p}<.05$

\section{Discussion}

This study found that Behavioral intention to use e-government service among employees of SMEs in Saudi Arabia plays an important and significant role as mediating variable in the relationship between facilitating condition and use behavior of e-government service, of SMEs Saudi Arabia. This positive impact is supported by some previous studies (Macedo, 2017;Alalwan, Dwivedi, \& Rana, 2017; Morosan \& Defranco, 2016; Hew, Lee, Ooi, \& Wei, 2015; Nair, Ali, \& Leong, 2015). It is explained by the fact that the more employees have the resources and knowledge necessary to use e-government service provided by Absher, the more the employees intend to continue using e-government service provided by Absher in daily life and in the future. However, this result contradicts some other studies in the IS context such as in (Baptista \& Oliveira, 2017), which found that there is no relationship between facilitating condition and behavioral intention in the context of mobile banking services in Portugal.

On other hand, facilitating condition does not significantly influence use behavior. The hypothesis is not supported, although this finding contradicts the result of several previous studies (Guo, 2015; Raman \& Don, 2013; Moghawemi, Salleh, Zhao, \& Mattila, 2012; Wu, Tao, \& Yang, 2007; Lin \& Anol, 2008; Im, Hong, \& Kang, 2011; Seppo Pahnila, 2011; Zhou, Lu, \& Wang, 2010; Boonsawat \& T.Naennab, 2014; EscobarRodríguez \& Carvajal-Trujillo, 2014), however, it is consistent with other studies (Fang, 2014; Yueh, Huang, \& Chang, 2015; Chia-Lin Hsu, Chen, Lin, Chang, \& Hsieh, 2014). This result may be because that the facilitating conditions such as providing the employees with the resources and knowledge necessary to use e-government service are not directly influence the use behavior but indirectly through the behavioral intention.

Then, facilitating condition found to has an indirect effect on the use behavior of e-government service via behavioral intention to use e-government service. This finding highlights the importance of ensuring the facilitating condition associated with the output of the use behavior. Finally; the positive impact of behavioral intention on user behavior in this study is supported in the prior research (Macedo, 2017; Baptista \& Oliveira, 2017; Nair, Ali, \& Leong, 2015; Raman \& Don, 2013; Tomás Escobar-Rodríguez \& Carvajal-Trujillo, 2013). It indicated that the more employees intend to continue using e-government service provided by Absher in daily life and in the future, the more employees plan to use the e-government service of SMEs in Saudi Arabia. 


\section{Conclusion}

The implications of the key findings provide significant benefits not only for individual employees but also to the Saudi Arabia public sector as well as the country if they utilize this information technology. This study found that mediation of intention to use is significant. This implies that facilitating conditions is critical for intention to use and behavior to use Absher online services. The implications of using the proposed model provides an understanding of the relationships of key determinants of facilitating conditions with to usage behavior under the mediation of intention to use, which helps to understand the motivation to consume egovernment service within the SME in Saudi Arabia.

Therefore, these findings should encourage and support the formation of future policy, not only at an organizational level but also at the national one.

\section{References}

1. AJZEN, I. 1991. The theory of planned behavior. Organizational behavior and human decision processes, 50, 179-211.

2. AL-AZRI, A., AL-SALTI, Z. \& AL-KARAGHOULI, W. 2010. The successful implementation of egovernment transformation: A case study in Oman.

3. AL-HUJRAN, O., AL-DEBEI, M. M., CHATFIELD, A. \& MIGDADI, M. 2015. The imperative of influencing citizen attitude toward e-government adoption and use. Computers in human Behavior, 53, 189203.

4. AL-KHATEEB, A., FAlOUDAH, A., BAHUMAYD, M. \& ZAFAR, A. 2015. E-Government Strategy and its impact on Economic Development of the Nation: A Case Study of the KSA. E-Government, 2.

5. AL IMARAH, A., ZWAIN, A. \& AL-HAKIM, L. 2013. The adoption of e-government services in the Iraqi Higher Education Context: An application of the UTAUT model in the University of Kufa. Journal of Information Engineering and Applications, 3, 77-84.

6. ALATEYAH, S., CROWDER, R. M. \& WILLS, G. B. 2013. Factors affecting the citizen's intention to adopt e-government in Saudi Arabia. International Journal of Social, Human Science and Engineering, 7, 80-85.

7. ALAWADHI, S. \& MORRIS, A. 2009. Factors influencing the adoption of e-government services. Journal of Software, 4, 584-590.

8. ALGHAMDI, S. \& BELOFF, N. 2016. Innovative Framework for e-Government adoption in Saudi Arabia: A Study from the business sector perspective. International Journal of Advanced Computer Science and Applications, 7, 655-664.

9. ALMATARI, A. Y., IAHAD, N. A. \& BALAID, A. S. 2013. Factors influencing students' intention to use mlearning. Journal of Information Systems Research and Innovation (JISRII), 5.

10. ALMOAWI, A. \& MAHMOOD, R. 2011. Applying the OTE model in determining the e-commerce adoption on SMEs in Saudi Arabia. Asian Journal of Business and Management Sciences, 1, 12-24.

11. ALNUAIMI, M., SHAALAN, K., ALNUAIMI, M. \& ALNUAIMI, K. Barriers to electronic government citizens' adoption: A case of municipal sector in the emirate of abu dhabi. Developments in E-systems Engineering (DeSE), 2011, 2011. IEEE, 398-403.

12. AlOTAIBI, M. B. 2015. Mobile computing trends in Saudi Arabia: An exploratory study. computing, 8, 9.

13. AlOTAIBI, R., SANDHU, K. \& HOUGHTON, L. 2014. A Study of Service Users' Attitudes towards EGovernment Initiatives in the Kingdom Of Saudi Arabia. IJCSIT) International Journal of Computer Science and Information Technologies, 5, 6892-6901.

14. ALRAJA, M. N. 2016. The effect of social influence and facilitating conditions on e-government acceptance from the individual employees' perspective. Polish Journal of Management Studies, 14.

15. ALSHEHRI, M. \& DREW, S. 2010. Challenges of e-government services adoption in Saudi Arabia from an e-ready citizen perspective. World Academy of Science, Engineering and Technology, 66.

16. ALSHEHRI, M., DREW, S. \& ALGHAMDI, R. 2013. Analysis of citizens acceptance for e-government services: Applying the UTAUT model. arXiv preprint arXiv:1304.3157.

17. ALZAHRANI, A. I., MAHMUD, I., RAMAYAH, T., ALFARRAJ, O. \& ALALWAN, N. 2017. Modelling digital library success using the DeLone and McLean information system success model. Journal of Librarianship and Information Science, 0961000617726123.

18. AlZAHRANi, S. H., BAKARMAN, M. A., ALQAHTANI, S. M., ALQAHTANI, M. S., BUTT, N. S., SALAWATI, E. M., ALKATHERI, A., MALIK, A. A. \& SAAD, K. 2018. Awareness of diabetic retinopathy among people with diabetes in Jeddah, Saudi Arabia. Therapeutic advances in endocrinology and metabolism, 9, 103-112. 
19. AWHEDA, A., AB RAHMAN, M. N., RAMLI, R. \& ARSHAD, H. 2016. Factors related to supply chain network members in SMEs. Journal of Manufacturing Technology Management, 27, 312-335.

20. BAHADDAD, A. A., ALGHAMDI, R. \& HOUGHTON, L. 2012. To what extent would E-mall enable SMEs to adopt e-commerce? arXiv preprint arXiv:1211.2402.

21. CERrATO, D., CROSATO, L. \& DEPPERU, D. 2016. Archetypes of SME internationalization: A configurational approach. International Business Review, 25, 286-295.

22. EL-SOFANY, H. F., AL-TOURKI, T., AL-HOWIMEL, H. \& AL-SADOON, A. 2012. E-Government in Saudi Arabia: Barriers, challenges and its role of development. International Journal of Computer Applications, 48.

23. FOON, Y. S. \& FAH, B. C. Y. 2011. Internet banking adoption in Kuala Lumpur: an application of UTAUT model. International Journal of Business and Management, 6, 161.

24. GHALANDARI, K. \& NOROUZI, A. 2012. The effect of country of origin on purchase intention: The role of product knowledge. Research Journal of Applied Sciences, Engineering and Technology, 4, 1166-1171.

25. GUPTA, B., DASGUPTA, S. \& GUPTA, A. 2008. Adoption of ICT in a government organization in a developing country: An empirical study. The Journal of Strategic Information Systems, 17, 140-154.

26. HAIR, HULT, RINGLE \& SARSTEDT 2017. A primer on partial least squares structural equation modeling (PLS-SEM) (2nd ed.), Thousand Oaks, Sage.

27. HAIR, J., F, BLACK, W., C, BABIN, B., J \& ANDERSON, R. E. 2013. Multivariate Data Analysis: Pearson New International Edition, Pearson Higher Ed.

28. HAIR, J., F, J \& ANDERSON, R., E 1998. Multivariate data analysis, London, UK, PrenticeHall International.

29. HARSONO, L. D. \& SURYANA, L. A. Factors affecting the use behavior of social media using UTAUT 2 model. Proceedings of the First Asia-Pasific Conference on Global Business, Economics, Finance and Social Sciences, Singapore, 2014.

30. JINJARAK, Y. \& WIGNARAJA, G. 2016. An Empirical Assessment of the Export-Financial Constraint Relationship: How Different are Small and Medium Enterprises? World Development, 79, 152-163.

31. KHAN, I. U., HAMEED, Z. \& KHAN, S. U. 2017. Understanding online banking adoption in a developing country: UTAUT2 with cultural moderators. Journal of Global Information Management (JGIM), 25, 43-65.

32. KRISHNARAJU, V., MATHEW, S. K. \& SUGUMARAN, V. 2016. Web personalization for user acceptance of technology: An empirical investigation of E-government services. Information Systems Frontiers, 18, 579-595.

33. LUO, J.-Z., JIN, J.-H., SONG, A.-B. \& DONG, F. 2011. Cloud computing: architecture and key technologies. Journal of China Institute of Communications, 32, 3-21.

34. MIDDLEEASTMONITOR 2018. Expatriates account for $69 \%$ of SME employees in Saudi Arabia. Available at: https://www.middleeastmonitor.com/20180315-report-expatriates-account-for-69-of-smeemployees-in-saudi-arabia/.

35. PREACHER, K. J. \& HAYES, A. F. 2008. Asymptotic and resampling strategies for assessing and comparing indirect effects in multiple mediator models. Behavior research methods, 40, 879-891.

36. RAKIĆEVIĆ, Z., OMERBEGOVIĆ-BIJELOVIĆ, J. \& LEČIĆ-CVETKOVIĆ, D. 2016. A model for effective planning of SME support services. Evaluation and program planning, 54, 30-40.

37. SARGENT, K., HYLAND, P. \& SAWANG, S. 2012. Factors influencing the adoption of information technology in a construction business. Australasian Journal of Construction Economics and Building, The, $12,72$.

38. SHARMA, S. K. 2015. Adoption of e-government services: The role of service quality dimensions and demographic variables. Transforming Government: People, Process and Policy, 9, 207-222.

39. SILVA, C. N. 2017. United Nations E-Government Survey 2016: E-Government in Support of Sustainable Development. IGI GLOBAL 701 E CHOCOLATE AVE, STE 200, HERSHEY, PA 17033-1240 USA.

40. THOMAS, T., SINGH, L. \& GAFFAR, K. 2013. The utility of the UTAUT model in explaining mobile learning adoption in higher education in Guyana. International Journal of Education and Development using ICT, 9.

41. VENKATESH, V., MORRIS, M. G., DAVIS, G. B. \& DAVIS, F. D. 2003. User acceptance of information technology: Toward a unified view. MIS quarterly, 425-478.

42. VOUTINIOTI, A. 2013. Determinants of user adoption of e-government services in Greece and the role of citizen service centres. Procedia Technology, 8, 238-244.

43. WU, M.-Y., YU, P.-Y. \& WENG, Y.-C. 2012. A Study on User Behavior for I Pass by UTAUT: Using Taiwan. Asia Pacific Management Review, 17, 91-110.

44. YESSER 2012. Second National e-Government Action Plan For Kingdom of Saudi Arabia. 